\title{
Nesterenkonia alba sp. nov., an alkaliphilic actinobacterium isolated from the black liquor treatment system of a cotton pulp mill
}

Correspondence
Bin Yao
yaobin@caas-bio.net.cn

\author{
Hui-Ying Luo, ${ }^{1}$ Ya-Ru Wang, ${ }^{1}$ Li-Hong Miao, ${ }^{2}$ Pei-Long Yang, ${ }^{1}$ \\ Peng-Jun Shi, ${ }^{1}$ Cheng-Xiang Fang, ${ }^{3}$ Bin Yao ${ }^{1}$ and Yun-Liu Fan ${ }^{4}$
}

${ }^{1}$ Key Laboratory for Feed Biotechnology of the Ministry of Agriculture, Feed Research Institute, Chinese Academy of Agricultural Sciences, Beijing 100081, PR China

${ }^{2}$ Department of Biotechnology and Pharmaceutical Engineering, Wuhan Polytechnic University, Wuhan 430023, PR China

${ }^{3}$ College of Life Sciences, Wuhan University, Wuhan 430072, PR China

${ }^{4}$ Biotechnology Research Institute, Chinese Academy of Agricultural Sciences, Beijing 100081, PR China

An alkaliphilic actinobacterium, designated strain CAAS $252^{\top}$, was isolated from the black liquor treatment system of a cotton pulp mill in Wuhan, China. Cells of strain CAAS $252^{\top}$ were Grampositive, non-motile, non-endospore-forming, short rod-shaped, and grew optimally at $42{ }^{\circ} \mathrm{C}$ and $\mathrm{pH} 9-10$ in the presence of $3 \%(\mathrm{w} / \mathrm{v}) \mathrm{NaCl}$. Strain CAAS $252^{\top}$ contained MK-7, MK-8 and MK-9 as the major menaquinones and anteiso- $C_{17: 0}$, anteiso- $C_{15: 0}$ and $C_{16: 0}$ as the predominant cellular fatty acids and had a peptidoglycan type of A $4 \alpha$, Lys-Gly-D-Asp. The DNA G + C content was $60.2 \mathrm{~mol} \%$. Based on analysis of 16S rRNA gene sequences (94.7-96.8\% similarity), DNA-DNA hybridization ( $<70 \%$ relatedness) and chemotaxonomic characteristics, strain CAAS $252^{\top}$ belonged to the genus Nesterenkonia, but differed from all recognized species. Therefore, it is proposed that strain CAAS $252^{\top}$ represents a novel species of the genus Nesterenkonia, for which the name Nesterenkonia alba sp. nov. is proposed. The type strain is CAAS $252^{\top}$ $\left(=\right.$ CCTCC AB $207011^{\top}=$ DSM $\left.19423^{\top}\right)$.

A number of novel species of the genus Nesterenkonia have been described in recent years. Currently, the genus comprises ten recognized species: Nesterenkonia halobia (Stackebrandt et al., 1995), Nesterenkonia lacusekhoensis (Collins et al., 2002), Nesterenkonia halotolerans (Li et al., 2004), Nesterenkonia xinjiangensis (Li et al., 2004), Nesterenkonia lutea (Li et al., 2005), Nesterenkonia sandarakina (Li et al., 2005), Nesterenkonia aethiopica (Delgado et al., 2006), Nesterenkonia jeotgali (Yoon et al., 2006), Nesterenkonia halophila (Li et al., 2008) and Nesterenkonia flava (Luo et al., 2008). Most of these species were isolated from hypersaline or alkaline habitats such as saline soil, solar salt, seafood, soda lake or alkaline wastewater. This paper focuses on the taxonomic characterization of a novel alkaliphilic actinobacterium, designated strain CAAS $252^{\mathrm{T}}$, isolated from the black liquor treatment system of a cotton pulp mill in Wuhan, China.

Strain CAAS $252^{\mathrm{T}}$ was isolated using the dilution plating method at $42{ }^{\circ} \mathrm{C}$ with carboxymethylcellulose sodium salt

The GenBank/EMBL/DDBJ accession number for the $16 \mathrm{~S}$ rRNA gene sequence of strain CAAS $252^{\top}$ is EU566871. medium (CMC; containing, $1^{-1}$ : peptone, $10 \mathrm{~g}$; yeast extract, $10 \mathrm{~g} ; \mathrm{NaCl}, 5 \mathrm{~g}$; carboxymethylcellulose sodium salt, $10 \mathrm{~g} ; \mathrm{KH}_{2} \mathrm{PO}_{4}, 1 \mathrm{~g} ; \mathrm{pH} 10$, adjusted with $\mathrm{NaOH}$ ). Subculturing was conducted on peptone yeast extract agar (PYA; containing, $1^{-1}$ : peptone, $8.0 \mathrm{~g}$; yeast extract, 3.0 g; $\mathrm{K}_{2} \mathrm{HPO}_{4}, 1.0 \mathrm{~g}$; EDTA, $3.5 \mathrm{mg} ; \mathrm{ZnSO}_{4} .7 \mathrm{H}_{2} \mathrm{O}$, $3.0 \mathrm{mg} ; \mathrm{FeSO}_{4} .7 \mathrm{H}_{2} \mathrm{O}, 3.0 \mathrm{mg} ; \mathrm{MnSO}_{4} . \mathrm{H}_{2} \mathrm{O}, 2.0 \mathrm{mg}$; $\mathrm{CuSO}_{4} .5 \mathrm{H}_{2} \mathrm{O}, 1.0 \mathrm{mg} ; \mathrm{H}_{3} \mathrm{BO}_{3}, 1.0 \mathrm{mg}$; agar, $15.0 \mathrm{~g}$; $\mathrm{NaHCO}_{3} / \mathrm{NaCO}_{3}, 0.1 \mathrm{~mol} ; \mathrm{pH}$ 10.0) and Luria-Bertani (LB) plates at $42{ }^{\circ} \mathrm{C}$ until a pure culture was obtained.

The morphological, physiological and biochemical characteristics of strain CAAS $252^{\mathrm{T}}$ were investigated using cultures grown on PYA. Cells of strain CAAS $252^{\mathrm{T}}$ were grown at $42{ }^{\circ} \mathrm{C}$ for $24-36 \mathrm{~h}$ and their morphology was observed using a light microscope (BH-2; Olympus) and transmission electron microscopy (H-600; Hitachi). Colony characteristics were examined by growing the bacterium on PYA and on solid LB medium at $42{ }^{\circ} \mathrm{C}$ and $\mathrm{pH} 10$ for 2 days ( $\mathrm{Li}$ et al., 2004). The optimum temperature for growth was determined by growing the isolate in liquid LB medium at temperatures ranging from 4 to $55{ }^{\circ} \mathrm{C}$. The $\mathrm{pH}$ optimum for growth was tested in LB 
Table 1. Comparison of phenotypic characteristics of strain CAAS $252^{\top}$ and recognized species of the genus Nesterenkonia

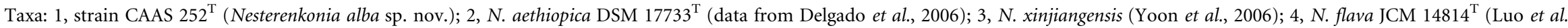

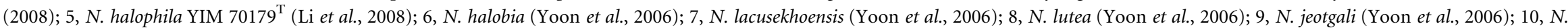
sandarakina (Yoon et al., 2006); 11, N. halotolerans (Yoon et al., 2006) +, Positive; -, negative; w, weak reaction; ND, not determined.

\begin{tabular}{|c|c|c|c|c|c|c|c|c|c|c|c|}
\hline Characteristic & 1 & 2 & 3 & 4 & 5 & 6 & 7 & 8 & 9 & 10 & 11 \\
\hline Morphology & Short rods & Short rods & Short rods & Short rods & Cocci & Cocci & Short rods & Cocci & Cocci & Cocci & Cocci \\
\hline Colony pigmentation & White & Yellow & Light yellow & Yellow & Ivory white & Colourless & Bright yellow & $\begin{array}{l}\text { Light yellow to } \\
\text { primrose } \\
\text { yellow }\end{array}$ & Light yellow & Orange-yellow & $\begin{array}{r}\text { Orange- } \\
\text { yellow }\end{array}$ \\
\hline Motility & - & - & - & - & - & - & - & + & - & - & + \\
\hline $\begin{array}{l}\text { Optimal temperature } \\
\left({ }^{\circ} \mathrm{C}\right)\end{array}$ & 42 & $30-37$ & 28 & $40-42$ & 28 & 30 & $27-33.5$ & 28 & $25-30$ & 28 & 28 \\
\hline $\mathrm{pH}$ tolerence & $8.0-12.0$ & $7.0-11.0$ & $7.0-12.0$ & $8.0-12.0$ & $6.0-10.5$ & $<6.0-10.0$ & $7.5-9.5$ & $6.5-10.0$ & $6.0-8.5$ & $5.0-12.0$ & $7.0-9.0$ \\
\hline $\mathrm{NaCl}$ tolerance $(\%)$ & $0-6$ & $3-12$ & $0-25$ & $0-10$ & $0.5-30$ & $5-23$ & $0-15$ & $0-20$ & $0-16$ & $1-16$ & $0-25$ \\
\hline Oxidase activity & - & + & - & - & - & + & - & - & - & - & - \\
\hline Urease & - & - & + & - & - & - & ND & - & - & - & + \\
\hline $\mathrm{H}_{2} \mathrm{~S}$ production & - & - & - & - & - & - & $\mathrm{W}$ & - & - & - & - \\
\hline Indole production & - & - & ND & - & - & - & - & - & - & - & - \\
\hline ONPG test ${ }^{*}$ & + & - & ND & - & + & ND & ND & + & - & + & + \\
\hline Nitrate reduction & - & ND & - & - & + & - & - & + & - & - & - \\
\hline Citrate test & - & - & ND & - & ND & - & $\mathrm{W}$ & ND & ND & ND & ND \\
\hline $\begin{array}{l}\text { Voges-Proskauer } \\
\text { reaction }\end{array}$ & - & $\mathrm{ND}$ & $\mathrm{ND}$ & - & - & + & - & - & + & - & + \\
\hline \multicolumn{12}{|l|}{ Hydrolysis of: } \\
\hline Starch & - & + & - & + & - & + & - & - & - & - & - \\
\hline Gelatin & + & + & + & + & - & - & - & - & - & + & + \\
\hline Tween 80 & + & ND & $\mathrm{ND}$ & + & - & - & - & - & - & - & - \\
\hline \multicolumn{12}{|l|}{ Utilization of: } \\
\hline D-Glucose & + & ND & + & + & + & ND & + & $\mathrm{w}$ & + & + & + \\
\hline D-Xylose & - & - & + & - & + & + & ND & + & + & + & - \\
\hline L-Arabinose & + & + & + & + & + & + & ND & $\mathrm{W}$ & + & W & - \\
\hline Cellobiose & - & $\mathrm{ND}$ & + & + & - & $\mathrm{ND}$ & ND & + & + & + & - \\
\hline Trehalose & $\mathrm{w}$ & - & - & - & ND & - & + & - & + & + & - \\
\hline D-Fructose & - & ND & + & + & + & ND & + & + & + & + & + \\
\hline D-Mannose & - & - & + & + & + & - & + & + & W & + & + \\
\hline Sucrose & + & $\mathrm{w}$ & + & + & ND & - & + & + & + & + & + \\
\hline Maltose & + & ND & + & + & ND & ND & + & + & + & + & + \\
\hline \multicolumn{12}{|l|}{ Acid production from: } \\
\hline D-Galactose & - & - & - & - & $\mathrm{ND}$ & $\mathrm{w}$ & - & + & + & + & - \\
\hline Lactose & - & - & - & - & - & + & - & + & - & - & - \\
\hline Trehalose & w & - & - & - & ND & - & + & + & $\mathrm{w}$ & - & - \\
\hline D-Xylose & - & - & - & - & - & + & - & + & + & + & - \\
\hline
\end{tabular}




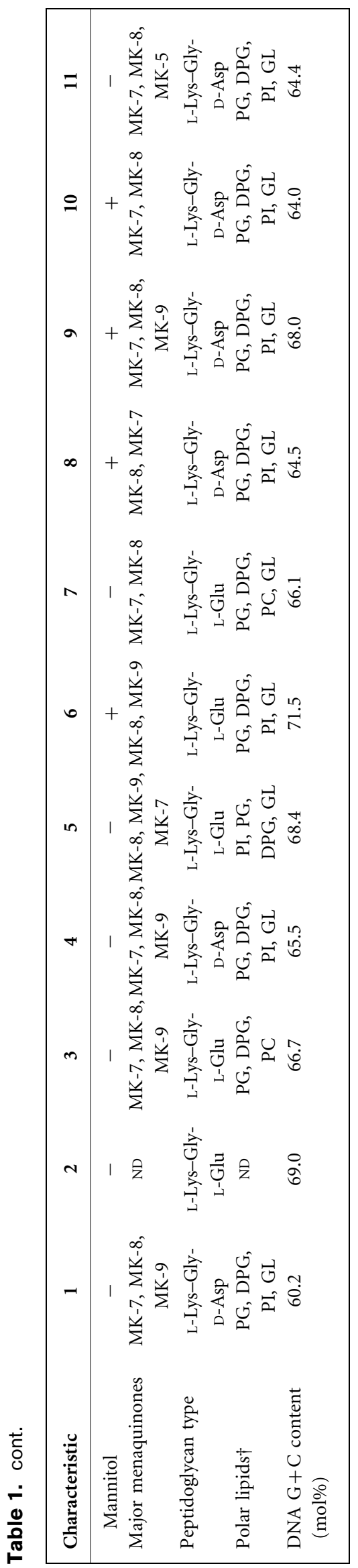

medium at $42{ }^{\circ} \mathrm{C}$ and $\mathrm{pH} 7-12$ using the buffer system given by Luo et al. (2008). Halotolerance was tested in LB medium supplemented with $0-15 \%(\mathrm{w} / \mathrm{v}) \mathrm{NaCl}$ at $\mathrm{pH} 10$ and $42{ }^{\circ} \mathrm{C}$. Catalase and oxidase activities were determined in $3 \%(\mathrm{v} / \mathrm{v}) \mathrm{H}_{2} \mathrm{O}_{2}$ and $1 \%(\mathrm{w} / \mathrm{v})$ tetramethyl-p-phenylenediamine, respectively. The utilization of various carbon sources was determined as described by Shirling \& Gottlieb (1966). Hydrolysis of starch, gelatin and Tween 80 were determined as described by Cowan \& Steel (1965). Nitrate reduction was determined according to the method of Lányí (1987) and acid production from carbohydrates was tested as described by Leifson (1963). Other physiological and biochemical tests were performed with the API $20 \mathrm{E}$ system (bioMérieux).

Biomass for analysis of menaquinones, cell wall and polar lipids and DNA extraction was grown on LB plates at $42{ }^{\circ} \mathrm{C}$ for 2 days. The cells were harvested and washed twice with sterile distilled water. The isolation and analysis of menaquinones, cellular fatty acids, polar lipids, peptidoglycan and the 16S rRNA gene were conducted according to Luo et al. (2008). Phylogenetic trees were generated using three methods, namely the neighbour-joining (Saitou \& Nei, 1987), maximum-parsimony (Fitch, 1971) and minimumevolution (Rzhetsky \& Nei, 1992) algorithms with MEGA version 4 (Tamura et al., 2007). The evolutionary distance method used for the neighbour-joining and minimumevolution methods was based on the Jukes-Cantor model (Jukes \& Cantor, 1969). Bootstrap values based on 1000 replications were used to evaluate the topology of the neighbour-joining tree. The DNA $\mathrm{G}+\mathrm{C}$ content was determined using the thermal denaturation method of De Ley (1970) with Escherichia coli K-12 as a control. DNADNA hybridization with the type strains of four closely related recognized Nesterenkonia species was determined by using the spectrophotometric method (De Ley et al., 1970; Huß et al., 1983). N. lacusekhoensis JCM $11953^{T}$ was obtained from Japan Collection of Microorganisms and $N$. aethiopica DSM $17733^{\mathrm{T}}$ and N. xinjiangensis DSM $15475^{\mathrm{T}}$ were obtained from the German Collection of Microorganisms and Cell Cultures. N. flava JCM $14814^{\mathrm{T}}$ was maintained in our laboratory (Luo et al., 2008).

The phenotypic and biochemical features of strain CAAS $252^{\mathrm{T}}$ in comparison with those of other Nesterenkonia species are given in Table 1 . Strain CAAS $252^{\mathrm{T}}$ could be distinguished from other Nesterenkonia species by means of the colour of the colonies, $\mathrm{NaCl}$ requirement and low DNA $\mathrm{G}+\mathrm{C}$ content. The cellular fatty acids of strain CAAS $252^{\mathrm{T}}$ and recognized Nesterenkonia species are compared in Table 2. The culture conditions used for the analysis of the cellular fatty acids were not the same as those described by Yoon et al. (2006), but the major fatty acid profile was generally similar to those of other Nesterenkonia species.

Multiple alignments of a nearly complete $16 \mathrm{~S}$ rRNA gene sequence (1494 nt) of strain CAAS $252^{\mathrm{T}}$ with those of other recognized Nesterenkonia species were carried out using CLUSTAL_X (Thompson et al., 1997) and the sequence 
Table 2. Cellular fatty acid composition of strain CAAS $252^{\top}$ and recognized species of the genus Nesterenkonia

Taxa: 1, strain CAAS $252^{\mathrm{T}}$ (Nesterenkonia alba sp. nov.); 2, N. xinjiangensis (Yoon et al., 2006); 3, N. flava JCM 14814 ${ }^{\mathrm{T}}$ (Luo et al., 2008); 4 , N. halophila YIM 70179 (Li et al., 2008); 5, N. halobia (Yoon et al., 2006); 6, N. lacusekhoensis (Yoon et al., 2006); 7, N. lutea (Yoon et al., 2006); 8, N. jeotgali (Yoon et al., 2006); 9, N. sandarakina (Yoon et al., 2006); 10, N. halotolerans (Yoon et al., 2006). Values are percentages of the total fatty acids. -, Not detected.

\begin{tabular}{|c|c|c|c|c|c|c|c|c|c|c|}
\hline Fatty acid & 1 & 2 & 3 & 4 & 5 & 6 & 7 & 8 & 9 & 10 \\
\hline $\mathrm{C}_{10: 0}$ & 0.56 & - & - & - & - & - & - & - & - & - \\
\hline $\mathrm{C}_{12: 0}$ & 0.55 & - & - & - & - & - & - & - & - & - \\
\hline iso- $\mathrm{C}_{14: 0}$ & - & 0.20 & - & 0.4 & - & 0.50 & 1.80 & 0.20 & 0.90 & 0.60 \\
\hline $\mathrm{C}_{14: 0}$ & 1.15 & - & 1.67 & - & - & 2.50 & 0.40 & 0.40 & 2.80 & - \\
\hline iso- $\mathrm{C}_{15: 1} \mathrm{G}$ & - & 1.20 & 0.62 & - & - & - & 1.00 & - & - & - \\
\hline anteiso- $\mathrm{C}_{15: 1} \mathrm{~A}$ & - & 0.40 & 0.86 & - & - & 0.60 & 7.80 & 0.40 & - & - \\
\hline iso- $\mathrm{C}_{15: 0}$ & 1.61 & 6.20 & 2.1 & 2.4 & 1.70 & 1.30 & 5.50 & 1.40 & 0.80 & 2.20 \\
\hline anteiso- $\mathrm{C}_{15: 0}$ & 11.02 & 21.90 & 34.80 & 47.1 & 33.80 & 62.10 & 53.60 & 43.70 & 59.70 & 72.80 \\
\hline $\mathrm{C}_{15: 0} 3-\mathrm{OH}$ & - & - & 1.26 & - & - & - & - & - & - & - \\
\hline $\mathrm{C}_{15: 0}$ & - & 0.20 & - & - & - & - & - & 0.90 & 2.10 & - \\
\hline iso- $\mathrm{C}_{16: 1} \mathrm{G}$ & 1.16 & 4.80 & 0.80 & - & - & - & 0.40 & - & - & - \\
\hline iso- $\mathrm{C}_{16: 0}$ & 3.71 & 9.60 & 7.30 & 11.2 & 8.30 & 6.70 & 17.80 & 13.00 & 4.40 & 9.80 \\
\hline$C_{16: 0}$ & 8.10 & 0.70 & 13.40 & 3.3 & 1.60 & 6.10 & 2.60 & 2.60 & 14.90 & 1.10 \\
\hline anteiso- $\mathrm{C}_{17: 1} \mathrm{~A}$ & 5.46 & 8.50 & - & - & - & - & - & - & - & - \\
\hline iso- $\mathrm{C}_{17: 0}$ & 1.76 & 6.20 & 0.80 & 1.3 & 2.30 & - & 0.50 & 1.70 & - & 0.40 \\
\hline anteiso- $\mathrm{C}_{17: 0}$ & 53.56 & 39.70 & 25.20 & 31.1 & 52.40 & 19.80 & 8.00 & 33.80 & 7.10 & 12.20 \\
\hline $\mathrm{C}_{18: 0}$ & 3.70 & - & 3.79 & - & - & - & - & 0.70 & 5.10 & - \\
\hline $\mathrm{C}_{18: 1} \omega 9 c$ & 3.03 & - & 1.80 & - & - & - & - & - & - & - \\
\hline \multicolumn{11}{|l|}{$\begin{array}{l}\text { Summed } \\
\text { features* }\end{array}$} \\
\hline 3 & 0.30 & - & 2.13 & - & - & - & - & - & - & - \\
\hline 5 & 0.50 & - & 0.70 & - & - & - & - & - & - & - \\
\hline 8 & 3.65 & - & 2.20 & - & - & - & - & - & - & - \\
\hline
\end{tabular}

*Summed features comprise a group of two or more fatty acids that could not be separated under the given conditions. Summed feature 3

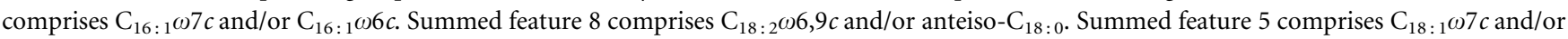
$\mathrm{C}_{18: 1} \omega 6 c$.

similarities were calculated using vector NTI software (Lu \& Moriyama, 2004). Based on the phylogenetic tree (Fig. 1), strain CAAS $252^{\mathrm{T}}$ was most closely related to $N$. aethiopica DSM $17733^{\mathrm{T}}$ (96.8\% gene sequence similarity), N. xinjiangensis DSM $15475^{\mathrm{T}}(96.6 \%)$ and N. flava JCM $14814^{\mathrm{T}}$
(96.1\%). The 16S rRNA gene sequence similarities to other Nesterenkonia species were $95.8 \%$ to N. halophila YIM $70179^{\mathrm{T}}, 95.5 \%$ to $N$. halobia JCM $11483^{\mathrm{T}}, 95.4 \%$ to $N$. lacusekhoensis JCM $11953^{\mathrm{T}}, 95.2 \%$ to $N$. lutea YIM $70081^{\mathrm{T}}$, $95.0 \%$ to $N$. jeotgali $\mathrm{JG}-241^{\mathrm{T}}, 94.9 \%$ to $N$. sandarakina YIM

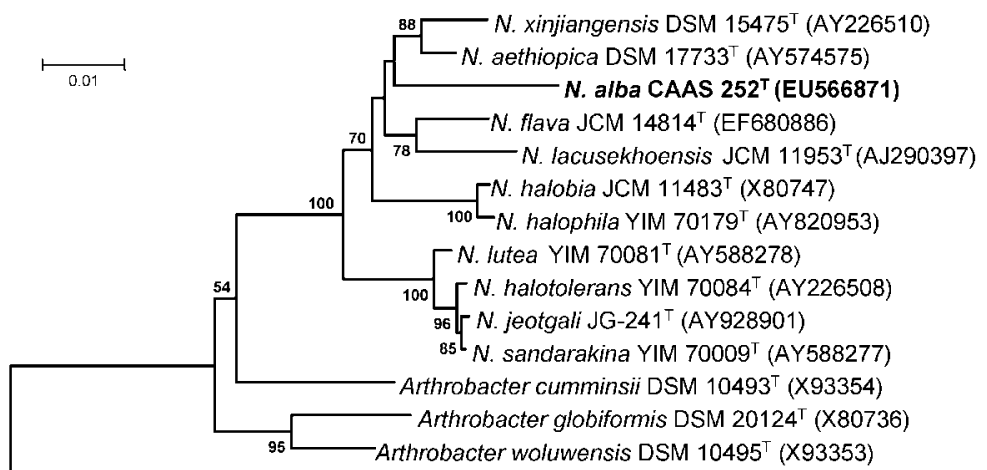

Streptomyces megasporus DSM $41476^{\top}$ (Z68100)
Fig. 1. Neighbour-joining phylogenetic tree, based on 16S rRNA gene sequences, showing the relationship between strain CAAS $252^{\top}$ and related taxa. Streptomyces megasporus DSM $41476^{\top}$ (Z68100) was used as an outgroup. Bootstrap values $(>50 \%)$ based on 1000 replications are shown at nodes. Bar, $1 \%$ sequence divergence. 
$70009^{\mathrm{T}}$ and $94.7 \%$ to $N$. halotolerans YIM $70084^{\mathrm{T}}$. The DNA $\mathrm{G}+\mathrm{C}$ content of strain CAAS $252^{\mathrm{T}}$ was $60.2 \mathrm{~mol} \%$. Furthermore, the DNA-DNA hybridization analysis of strain CAAS $252^{\mathrm{T}}$ revealed $60.7 \%$ DNA-DNA relatedness with respect to N. aethiopica DSM $17733^{\mathrm{T}}, 57.2 \%$ with respect to N. lacusekhoensis JCM $11953^{\mathrm{T}}, 41.7 \%$ with respect to $N$. flava JCM $14814^{\mathrm{T}}$ and $35.0 \%$ with respect to $N$. xinjiangensis CCTCC AA $001025^{\mathrm{T}}$. In view of the threshold values for the delineation of genomic species, i.e. 97\% 16S rRNA gene similarity (Stackebrandt \& Goebel, 1994) and $70 \%$ DNADNA relatedness (Wayne et al., 1987), it is evident that strain CAAS $252^{\mathrm{T}}$, isolated from a black liquor-treatment system, represents a previously unknown species. Therefore, strain CAAS $252^{\mathrm{T}}$ represents a novel species of the genus Nesterenkonia, for which the name Nesterenkonia alba sp. nov. is proposed.

\section{Description of Nesterenkonia alba sp. nov.}

Nesterenkonia alba (al'ba. L. fem. adj. alba white, referring to the colour of colonies of the organism).

Cells are Gram-positive, non-motile, non-spore-forming, short rods, $0.4-0.6 \mu \mathrm{m}$ in width and $0.8-1.2 \mu \mathrm{m}$ in length. Colonies on solid LB medium are white, smooth, circular and approximately $0.9-1.2 \mathrm{~mm}$ in diameter at $42{ }^{\circ} \mathrm{C}$ at $48 \mathrm{~h}$. The surface of the colonies is moist and glistening. Growth occurs at $20-50{ }^{\circ} \mathrm{C}$ and $\mathrm{pH} 8-12$, and with $0-6 \%$ (w/v) $\mathrm{NaCl}$. Optimum conditions for growth are $42{ }^{\circ} \mathrm{C}$ and $\mathrm{pH} 9-10$, with $3 \% \mathrm{NaCl}$. Catalase-positive but negative for oxidase, urease and the methyl red reaction. Does not produce $\mathrm{H}_{2} \mathrm{~S}$ or indole. Glucose, arabinose, sucrose, maltose, xylitol, melibiose, melezitose, raffinose, trehalose and glycerol are utilized, but mannose, fructose, xylose, Dgalactose, $\alpha$-D-lactose, arabitol, cellobiose, adonitol and sorbitol are not. Negative for hydrolysis of starch and positive for hydrolysis of Tween 80 and gelatin. Acid is not produced from D-galactose, lactose, xylose or mannitol. Major menaquinones are MK-7 (9.7\%), MK-8 (54.8\%) and MK-9 $(35.5 \%)$. Fatty acids are anteiso- $\mathrm{C}_{17: 0}$, anteiso$\mathrm{C}_{15: 0}, \mathrm{C}_{16: 0}$, anteiso- $\mathrm{C}_{17: 1} \mathrm{~A}$, iso- $\mathrm{C}_{16: 0}, \mathrm{C}_{18: 0}$, summed feature $8\left(\mathrm{C}_{18: 1} \omega 7 c\right.$ and/or $\left.\mathrm{C}_{18: 1} \omega 6 c\right), \mathrm{C}_{18: 1} \omega 9 c$, iso- $\mathrm{C}_{17: 0}$, iso- $\mathrm{C}_{15: 0}, \mathrm{C}_{14: 0}, \mathrm{C}_{10: 0}, \mathrm{C}_{12: 0}$, summed feature 5 $\left(\mathrm{C}_{18: 2} \omega 6,9 c\right.$ and/or anteiso- $\left.\mathrm{C}_{18: 0}\right)$ and summed feature 3 $\left(\mathrm{C}_{16: 1} \omega 7 c\right.$ and/or $\left.\mathrm{C}_{16: 1} \omega 6 c\right)$. Cell-wall peptidoglycan type is A4 $\alpha$, Lys-Gly-D-Asp. Polar lipids are phosphatidylglycerol, diphosphatidylglycerol, phosphatidylinositol and unidentified glycolipids. The DNA G $+\mathrm{C}$ content of the type strain is $60.2 \mathrm{~mol} \%$.

The type strain, CAAS $252^{\mathrm{T}}\left(=\right.$ CCTCC AB $207011^{\mathrm{T}}=$ DSM $19423^{\mathrm{T}}$ ), was isolated from the black liquor treatment system of a cotton pulp mill in Wuhan, China.

\section{Acknowledgements}

This work was supported by the National Agricultural Microorganism Resources program of China (Grant no. 2005 DKA21201). We thank Professor Tian-Shen Tao for his excellent assistance.

\section{References}

Collins, M. D., Lawson, P. A., Labrenz, M., Tindall, B. J., Weiss, N. \& Hirsch, P. (2002). Nesterenkonia lacusekhoensis sp. nov., isolated from hypersaline Ekho Lake, East Antarctica, and emended description of the genus Nesterenkonia. Int J Syst Evol Microbiol 52, 1145-1150.

Cowan, S. T. \& Steel, K. J. (1965). Manual for the Identification of Medical Bacteria. London: Cambridge University Press.

De Ley, J. (1970). Reexamination of the association between melting point, buoyant density, and chemical base composition of deoxyribonucleic acid. J Bacteriol 101, 738-754.

De Ley, J., Cattoir, H. \& Reynaerts, A. (1970). The quantitative measurement of DNA hybridization from renaturation rates. Eur J Biochem 12, 133-142.

Delgado, O., Quillaguamán, J., Bakhtiar, S., Mattiasson, B., Gessesse, A. \& Hatti-Kaul, R. (2006). Nesterenkonia aethiopica sp. nov., an alkaliphilic, moderate halophile isolated from an Ethiopian soda lake. Int J Syst Evol Microbiol 56, 1229-1232.

Fitch, W. M. (1971). Toward defining the course of evolution: minimum change for a specific tree topology. Syst Zool 20, 406-416.

Huß, V. A. R., Festl, H. \& Schleifer, K. H. (1983). Studies on the spectrophotometric determination of DNA hybridization from renaturation rates. Syst Appl Microbiol 4, 184-192.

Jukes, T. H. \& Cantor, C. R. (1969). Evolution of protein molecules. In Mammalian Protein Metabolism, vol. 3, pp. 21-132. Edited by H. N. Munro. New York: Academic Press.

Lányí, B. (1987). Classical and rapid identification methods for medically important bacteria. Methods Microbiol 19, 1-67.

Leifson, E. (1963). Determination of carbohydrate metabolism of marine bacteria. J Bacteriol 85, 1183-1184.

Li, W.-J., Chen, H.-H., Zhang, Y.-Q., Schumann, P., Stackebrandt, E., Xu, L.-H. \& Jiang, C.-L. (2004). Nesterenkonia halotolerans sp. nov. and Nesterenkonia xinjiangensis sp. nov., actinobacteria from saline soils in the west of China. Int J Syst Evol Microbiol 54, 837-841.

Li, W.-J., Chen, H.-H., Kim, C.-J., Zhang, Y.-Q., Park, D.-J., Lee, J.-C., Xu, L.-H. \& Jiang, C.-L. (2005). Nesterenkonia sandarakina sp. nov. and Nesterenkonia lutea sp. nov., novel actinobacteria, and emended description of the genus Nesterenkonia. Int J Syst Evol Microbiol 55, 463-466.

Li, W.-J., Zhang, Y.-O., Schumann, P., Liu, H.-Y., Yu, L.-Y., Zhang, Y.-Q., Stackebrandt, E., Xu, L.-H. \& Jiang, C.-L. (2008). Nesterenkonia halophila sp. nov., a novel moderately halophilic and alkalitolerant actinobacterium isolated from a saline soil. Int J Syst Evol Microbiol 58, 1359-1363.

Lu, G. \& Moriyama, E. N. (2004). Vector NTI, a balanced all-in-one sequence analysis suite. Brief Bioinform 5, 378-388.

Luo, H.-Y., Miao, L.-H., Fang, C., Yang, P.-L., Wang, Y.-R., Shi, P.-J., Yao, B. \& Fan, Y.-L. (2008). Nesterenkonia flava sp. nov., isolated from paper mill effluent. Int J Syst Evol Microbiol 58, 1927-1930.

Rzhetsky, A. \& Nei, M. (1992). Statistical properties of the ordinary least-squares, generalized least-squares, and minimum-evolution methods of phylogenetic inference. J Mol Evol 35, 367-375.

Saitou, N. \& Nei, M. (1987). The neighbor-joining method: a new method for reconstructing phylogenetic trees. Mol Biol Evol 4, 406425.

Shirling, E. B. \& Gottlieb, D. (1966). Methods for characterization of Streptomyces species. Int J Syst Bacteriol 16, 313-340.

Stackebrandt, E. \& Goebel, B. M. (1994). Taxonomic note: a place for DNA-DNA reassociation and $16 \mathrm{~S}$ rRNA sequence analysis in the present species definition in bacteriology. Int J Syst Bacteriol 44, 846-849. 
Stackebrandt, E., Koch, C., Gvozdiak, O. \& Schumann, P. (1995). Taxonomic dissection of the genus Micrococcus: Kocuria gen. nov., Nesterenkonia gen. nov., Kytococcus gen. nov., Dermacoccus gen. nov., and Micrococcus Cohn 1872 gen. emend. Int J Syst Bacteriol 45, 682692.

Tamura, K., Dudley, J., Nei, M. \& Kumar, S. (2007). MEGA4: Molecular Evolutionary Genetics Analysis (MEGA) software version 4.0. Mol Biol Evol 24, 1596-1599.

Thompson, J. D., Gibson, T. J., Plewniak, F., Jeanmougin, F. \& Higgins, D. G. (1997). The CLUSTAL_X windows interface: flexible strategies for multiple sequence alignment aided by quality analysis tools. Nucleic Acids Res 25, 4876-4882.

Wayne, L. G., Brenner, D. J., Colwell, R. R., Grimont, P. A. D., Kandler, O., Krichevsky, M. I., Moore, L. H., Moore, W. E. C., Murray, R. G. E. \& other authors (1987). International Committee on Systematic Bacteriology. Report of the ad hoc committee on reconciliation of approaches to bacterial systematics. Int J Syst Bacteriol 37, 463-464.

Yoon, J.-H., Jung, S.-Y., Kim, W., Nam, S.-W. \& Oh, T.-K. (2006).

Nesterenkonia jeotgali sp. nov., isolated from jeotgal, a traditional Korean fermented seafood. Int J Syst Evol Microbiol 56, 2587-2592. 